\title{
EVALUATING IMPRESSION OF VERTICAL GREENERY USING SD METHOD \\ SD 法を用いた壁面緑化の印象評価
}

\author{
Kenji NAKAMURA*, Michihiro KITA** and Kanji MATSUMOTO*** \\ 中村健二, 木多道宏, 松本幹治
}

\begin{abstract}
Vertical greenery in buildings is coming into increased use in recent years. Since vertical greenery directly affects the appearance of a building, it is necessary to study the impression of vertical greenery design in order to improve the urban landscape as well as to provide a comfortable living environment to urban people.

In this study, the semantic differential (SD) method was used for evaluating 14 buildings with vertical greenery in urban areas so as to identify the evaluating impression of vertical greenery designs. The results of this study are the following:

1. Three factors were used in the following order during the evaluation: "Visual Beauty", "Harmony" and "Potency".

2. Among various types of greening methods, the unit-type greening method in which plants were allocated at the bottom of the building in a landscape-oriented space and in which green coverage was 35-50\% was highly rated.

3. There was a gender difference; male tended to value "Potency". There was a generation difference; 20 's and 30's tended to value "Visual Beauty" and 40's and 50's tended to value "Potency".
\end{abstract}

Keywords: Vertical Greenery, Design, Semantic Differential Method, Factor Analysis

壁面緑化，デザイン，SD 法，因子分析

\section{Introduction}

Greening of buildings is being used increasingly for reducing the heat-island effect or for improving the landscape beauty in cities. In particular, the vertical greenery area was $2,355 \mathrm{~m}^{2}$ in 2000 , it rapidly increased almost 21 times to $49,247 \mathrm{~m}^{2}$ by $2007^{1)}$ in Japan.

While the interest for the vertical greenery technology of Japan has risen in foreign countries and the authors have received a lot of inquiries for the vertical greenery technology from countries such as Singapore, Malaysia, Canada, and Australia.

Greening of building walls, however, directly affects the appearance of a building, and in order to improve both the city landscape and comfort of those who live in cities, it is necessary to clarify the points to design more ideal vertical greenery.

Some of the past studies on vertical greenery design are the following.

Koba et al. ${ }^{2,3)}$ conducted a survey regarding vertical greenery among foreign students in Japan and general Japanese public to identify the factors contributing to the perception of an ideal vertical greenery design in subtropical cities in Okinawa and Southeast Asia. The results showed that it was desirable that 40 to $50 \%$ of the wall surface is covered with plants and that the greening is designed integrally with the architecture of the building.

Sawada et al. ${ }^{4,5)}$ studied the visual perception effects of vertical greenery by conducting interviews and psychological assessment experiments using prepared models of vertical greenery. The study revealed the strong relationship between the building with greenery and its surrounding buildings, as well as the extent of reduction of oppressive feeling by the building greenery, by showing the influence of the greening planar patterns on the perceived level of harmony between that building and the surrounding buildings.

Okita et al. ${ }^{6,7)}$ carried out vertical greening in virtual reality and suggested that the greening contributes to the improvement of the building value in terms of the overall impression, visual features, and design.

Sakuma et al. ${ }^{8}$ conducted interviews with the general public using the evaluation grid method to study their criteria for judging vertical greenery in buildings. The result showed that, in addition to the impression that they got from greening plants, good balance among the level of artificiality, relationship between the building and its surroundings, harmony with nature, and appearance of planning were also important for good design.

The present authors ${ }^{9)}$ made a comparative study of building wall
* Senior Research Engineer, Institute of Technology, SHIMIZU CORPORATION

* Assoc. Prof., Dept. of Architectural Engineering, Graduate School of Engineering, Osaka University

*** Prof., Dept. of Materials Science and Chemical Engineering, Graduate School of Engineering, Yokohama National University
清水建設侏技術研究所 主任研究員・工博

大阪大学大学院工学研究科 准教授·工博

横浜国立大学大学院工学研究院 教授. 工博 
designs by actually moving vertical greening panels and found that a well-balanced arrangement of greening panels on building walls is important. It was confirmed that the time of day and the weather at the time of assessment has influenced the result and that it is important to conduct the assessment at various distances from the building, such as the location far from the building to allow the respondents to evaluate the harmony between the building and the surrounding environment, the location close to the building so that the respondents can feel the plants.

For this reason, pictures of the target buildings were taken again on clear days around the same time. For each building, a close-up of the walls, a picture of the entire building, and a picture showing the target building and its surrounding environment were taken. As a result of reassessment using these pictures, it was clear that it was necessary to arrange greening panels on the walls with a good overall balance, to keep the plants dense at the bottom of the walls, and to avoid creating any complicated design patterns ${ }^{10)}$

Köhler ${ }^{11)}$ reviewed research activities on the green wall and façade technology in Germany and he clarified the potential of green facades to improve urban microclimate and buildings' ecological footprint is high.

Wong et al. ${ }^{12)}$ evaluated eight different vertical greenery systems installed in "HortPark" and they clarified the potential thermal benefits of them in reducing the surface temperature of buildings facades in tropical climate, leading to a reduction in the cooling load and energy cost.

As described above, studies on vertical greenery design have been conducted from a wide variety of aspects. Recently, however, many variations of greening technology called the 'unit-type' technology have been developed, and with this 'unit-type' technology, greening panels can be installed on building walls with high design flexibility. It is necessary to reexamine greening technologies including this 'unit-type' technology, to clarify the points to design more ideal vertical greenery.

The target of the present study was limited to urban buildings and it was attempted to identify clearly the important points to be considered when designers incorporated vertical greenery into their building designs. Therefore, in cities such as Tokyo, Yokohama, and Osaka, 14 buildings with vertical greenery were selected from pioneering buildings to latest buildings. Many of them won awards in vertical greenery-related competitions held by the Organization for Landscape and Urban Green Technology Development or by Yokohama City.

Next, the SD method was used to evaluate the design of these buildings Factor analysis of the assessment results was also made, factors for evaluating vertical greenery design were extracted, and mixed analysis of variance as well as multiple comparisons were conducted in order to examine the relationship between the vertical greenery design and the overall assessment score and also to examine the gender and age differences in such scores. This paper reports the findings of our experiments

\section{Method}

\subsection{Assessment Examples and Characteristics of Vertical Greenery Designs}

Brief descriptions of the 14 sample buildings that were assessed in this study and features of each vertical greenery design are listed in Table 1. Photographs were take of each sample (hereafter referred to as "design") at a long distance (from where both the target building and its surrounding environment could be seen), at a medium distance (the entire target building could be seen), and a close distance (as close to the building as possible). These photos were taken from places such as roads and pedestrian overpasses from where the vertical greenery could be observed. Photo.1 shows sample pictures of each design, and Photo. 2 shows a sample design sheet. Pictures were taken with a Panasonic DMC-TZ3 camera and a Ricoh Caplio GX100 camera, with focal length fixed of 28 mm equivalent, on clear days between July 29, 2007 and November 5, 2007.

Note that, for Buildings $\mathrm{A}$ and $\mathrm{E}$ that were pioneering examples, the plants were not well maintained and some parts of them had dried when the pictures were taken. We therefore used the image-editing software Adobe Photoshop CS2 to make the plants appear greener in the pictures.

The green coverage ratio shown in Table 1 indicates the percentage of

Table 1. Profile of 14 Buildings and Design Feature of their Vertical Greenery

\begin{tabular}{|c|c|c|c|c|c|c|c|c|c|c|}
\hline \multirow[b]{2}{*}{ Name } & \multirow[b]{2}{*}{ Address } & \multirow[b]{2}{*}{ Scale } & \multirow{2}{*}{$\begin{array}{c}\text { Area of } \\
\text { Green } \\
\text { Wall } \\
\left(\mathrm{m}^{2}\right)\end{array}$} & \multirow[b]{2}{*}{$\begin{array}{c}\text { Greening } \\
\text { Method }\end{array}$} & \multirow[b]{2}{*}{ Shape } & \multirow[b]{2}{*}{$\begin{array}{l}\text { Greenery } \\
\text { Position }\end{array}$} & \multicolumn{2}{|c|}{ Green Coverage Ratio (\%) } & \multirow{2}{*}{$\begin{array}{c}\text { Volume of } \\
\text { Surrounding } \\
\text { Greenery }\end{array}$} & \multirow[b]{2}{*}{$\begin{array}{l}\text { Wall } \\
\text { Color }\end{array}$} \\
\hline & & & & & & & Only Wall ${ }^{\mathrm{g})}$ & $\begin{array}{c}\text { Include Street } \\
\text { Trees }\end{array}$ & & \\
\hline $\mathrm{A}$ & Chuo-Ku Tokyo & B3F \& 7F & 90 & $\mathrm{HD}^{\mathrm{a})}$ & $\mathrm{HL}^{\mathrm{c})}$ & Other $^{\mathrm{f}}$ & 23 & 23 & Small & White \& Gray \\
\hline $\mathrm{B}$ & Yokohama city & $7 \mathrm{~F}$ & 483 & $\mathrm{CU}^{\mathrm{b})}$ & Other $^{\mathrm{e})}$ & Other & 71 & 71 & Medium & White \\
\hline $\mathrm{C}$ & Minato-Ku Tokyo & $6 \mathrm{~F}$ & 98 & $\mathrm{HD}$ & $\mathrm{VL}^{\mathrm{d})}$ & Lower & 14 & 14 & Small & White \\
\hline $\mathrm{D}$ & Kobe city & $\mathrm{B} 1 \mathrm{~F} \& 4 \mathrm{~F}$ & 1,431 & $\mathrm{CU}$ & Other & Other & 45 & 66 & Large & Black \\
\hline $\mathrm{E}$ & Minato-Ku Tokyo & $9 \mathrm{~F}$ & 160 & $\mathrm{CU}$ & VL & Other & 35 & 35 & Small & White \\
\hline $\mathrm{F}$ & Toshima-Ku Tokyo & $\mathrm{B} 2 \mathrm{~F} \& 12 \mathrm{~F}$ & 250 & Unit & VL & Other & 2 & 2 & Small & White \\
\hline $\mathrm{G}$ & Saitama city & $\mathrm{B} 1 \mathrm{~F} \& 7 \mathrm{~F}$ & 1,000 & Unit & $\mathrm{HL}$ & Lower & 16 & 28 & Small & Gray \\
\hline $\mathrm{H}$ & Nagoya city & $2 \mathrm{~F}$ & 630 & $\mathrm{CU}$ & Other & Other & 80 & 80 & Small & White \\
\hline $\mathrm{I}$ & Suita city Osaka & $4 \mathrm{~F}$ & 85 & Unit & $\mathrm{VL}$ & Other & 36 & 36 & Small & Gray \\
\hline $\mathrm{J}$ & Chiyoda-Ku Tokyo & $\mathrm{B} 2 \mathrm{~F} \& 14 \mathrm{~F}$ & 675 & Unit & $\mathrm{HL}$ & Lower & 25 & 25 & Small & White \\
\hline $\mathrm{K}$ & Yokohama city & $\mathrm{B} 1 \mathrm{~F} \& 3 \mathrm{~F}$ & 90 & $\mathrm{CU}$ & $\mathrm{VL}$ & Lower & 34 & 34 & Large & White \& Gray \\
\hline $\mathrm{L}$ & Kita-Ku Tokyo & $1 \mathrm{~F}$ & 20 & Moss & Other & Upper & 27 & 27 & Small & Pink \\
\hline $\mathrm{M}$ & Urayasu city & $\mathrm{B} 1 \mathrm{~F} \& 6 \mathrm{~F}$ & 250 & Unit & $\mathrm{HL}$ & Lower & 13 & 33 & Medium & White \\
\hline $\mathrm{N}$ & Yokohama city & $\mathrm{B} 2 \mathrm{~F} \& 8 \mathrm{~F}$ & 1,000 & Unit & $\mathrm{HL}$ & Other & 13 & 58 & Medium & White \\
\hline
\end{tabular}

a) "HD" means that vines are hanging down from upper side. b) "CU" means that vines are climbing up to the upper side. c) "HL" means the horizontally long shape.

d) "VL" means vertically long shape. e) "Other" means the shape other than "HL" and "VL". f) "Other" means the position other than "Upper" and "Lower".

g) "Only Wall" means the ratio of the area of the wall covered by plants that doesn't include street trees. 


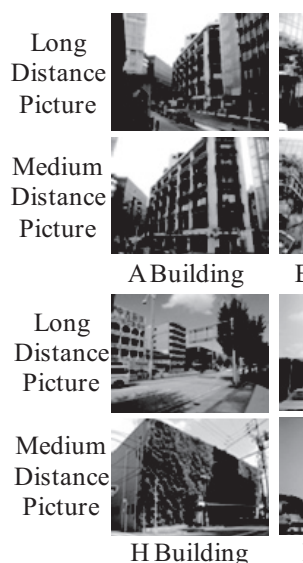

HBuilding

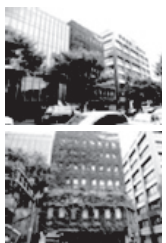

B Building

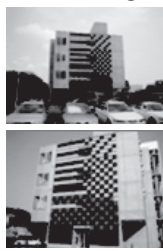

I Building

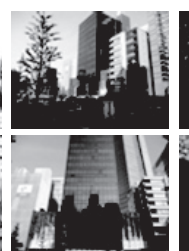

C Building

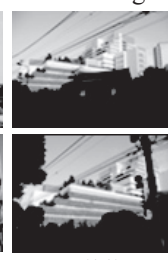

J Building

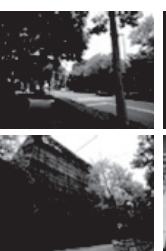

D Building

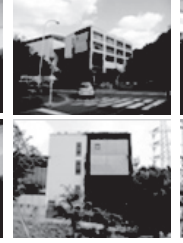

K Building

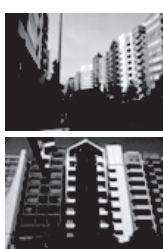

E Building

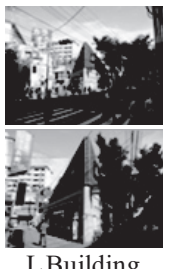

L Building

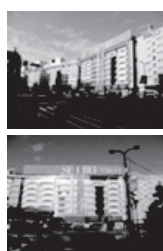

F Building

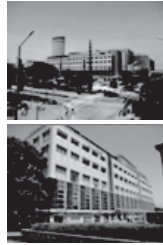

M Building

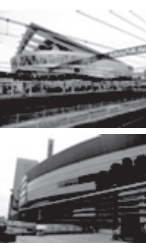

G Building

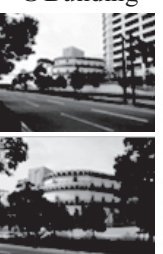

N Building

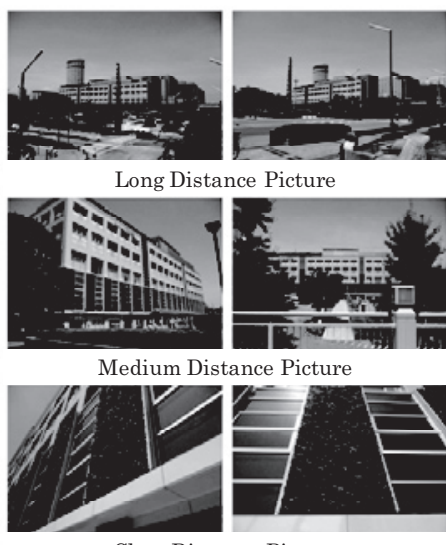

Close Distance Picture

Photo. 1. 14 Buildings with Vertical Greenery

the building surface area that was covered by plants based on the medium distance picture, and the building surface area and the area covered by plants were both obtained through histogram analysis using the same software as above, Adobe Photoshop CS2. Street trees covering building walls were included in the green coverage calculation. The amount of surrounding greenery was obtained based on the ratio of the amount of street trees to the total building wall surface area seen in long distance pictures, and in the table, 'Large' means that the volume of street trees was larger than the wall surface area, 'Medium' means that the volume of street trees was approximately the same as the wall surface area, and 'Small' means that the volume of street trees was smaller than the wall surface area.

\subsection{Assessment Method}

These 14 designs were assessed by the SD method consisting of the 18 evaluation parameters as shown in Table 2. These parameters were selected by first adding greening-related items to be evaluated to adjective pairs generally used in building appearance assessment ${ }^{13)}$, next carrying out factor analysis of the results of our study in the Osaka University FRC research building, and finally by selecting the ones that would be appropriate for the purpose of this study. Assessment was then carried out using a 7-point scale, and the intermediate value indicating 'neither' was a score of '4.' NO.18 of evaluation items means an overall judgment score of the building with vertical greenery.

As shown in Table 3, there were 52 Japanese respondents who work Construction Company in all, with 26 males and 26 females, and gender differences were measured between these two gender groups. Also, age differences were measured between the group of 26 respondents in their 20 's or 30's and another group of 26 respondents in their 40's or 50's. We created four types of questionnaires containing the same but differently ordered images of these 14 designs, and administered them to the respondents randomly divided into four groups.

\subsection{Analysis of Assessment Results}

In order to identify the factors, factor analysis was conducted with the assessment results. These factors were selected through maximum likelihood estimation, and the number of factors was set to three based on a scree plot. Further, oblique rotations produced by the oblimin method
Photo. 2. Example of Design Sheet
Table 2. Evaluation Items of SD method

\section{Evaluation Items*}

1. Disharmonious or Harmonious with surroundings, 2. Disharmonious or Harmonious with building, 3. Disharmonious or Harmonious of color between surrounding and wall, 4. Disharmonious or Harmonious of color between building and wall, 5. Unfamiliar-Familiar, 6. Artificial - Natural, 7. Cluttered-Ordered, 8. Ugly-Beautiful, 9. Monotonous-Varied, 10. RichPoor (volume of greenery), 11. Plain-Gorgeous, 12. Heavy-Light, 13. Ordinary-Unique, 14. Stale-Fresh, 15. Dull-Clear, 16. Dry-Moist, 17. Dark-Bright, 18. Bad - Good as overall judgment

* Those items were shown in Japanese exactly.

Table 3. Respondents

\begin{tabular}{cccc}
\hline Group & Gender & Age Group & Number of Persons \\
\hline 1 & \multirow{2}{*}{ Males } & $20-30 \mathrm{~s}$ & 13 \\
\cline { 1 - 1 } \cline { 4 - 4 } 2 & & $40-50 \mathrm{~s}$ & 13 \\
\hline 3 & \multirow{2}{*}{ Females } & $20-30 \mathrm{~s}$ & 13 \\
\cline { 1 - 1 } \cline { 4 - 4 } & & $40-50 \mathrm{~s}$ & 13 \\
\hline
\end{tabular}

were used. No items were deleted. The correlations between the factors and overall scores were analyzed by the multiple linear regression analysis (stepwise procedure) using the factor scores.

Next, in order to clarify the relationship between the design and its overall judgment score, mixed analysis of variance was conducted with the overall score for each gender, age group, and design. For each design, unpaired t-test and multiple comparisons were conducted with the overall scores obtained from each gender and age group. Next, the relationship between the evaluating factor and overall scores was analyzed. Also, gender and age differences for individual factors were analyzed. Furthermore, designs with biased overall scores also became the target of analysis.

Depending on the overall scores, interviews were carried out when necessary with the respondents to ask for a reason for the scores that they gave. For each design, interviews were carried out with eight respondents who gave the score that it most frequently received. If, for a particular design, there were two most frequently received scores, four respondents were interviewed for each of these scores. 


\section{Results}

\subsection{Comprehensive Assessment of the 14 Designs}

Table 4 shows the average overall scores for each design. Among the 14 designs, 11 of them received a score higher than 4, which was the middle value, and Buildings $\mathrm{M}, \mathrm{I}, \mathrm{J}, \mathrm{N}$, and $\mathrm{G}$ received a score of 5 or higher for "Slightly Good." On the other hand, Buildings B, H, and F received a score between 3.0 and 3.99, indicating that the design was "Slightly Bad." There were no buildings that were rated as being "Bad" or "Very Bad."

The 14 designs selected for this study were, as described above, highly recognized pioneering designs or award-winning designs, and this study reconfirmed that they had good wall greenery designs.

\subsection{Evaluating Factors}

Table 5 shows the result of factor analysis conducted with the answers provided on the questionnaire regarding the 14 designs.

Six parameters such as Brightness, Vividness, Lightness, and Beauty, etc. were selected for the first factor which was then labeled as "Visual Beauty". Six parameters related to the surrounding environment were selected for the second factor which was then labeled as "Disharmony". The third factor was labeled as "Potency" due to the selection of five parameters such as Feeling of Green, Variety, and Uniqueness, etc.

\subsection{Relationship between the Factors and Overall Judgment Scores}

Table 6 and 7 shows the result of multiple linear regression analysis conducted with overall scores for three factors. Consequently, a significant correlation ( $\mathrm{R}=0.869)$ was obtained, and Visual Beauty, Disharmony, and Potency were extracted as a significant explaining variable.

\subsection{Relationship between the Designs and Overall Judgment Scores}

Mixed analysis of variance was conducted with the Good as Overall Judgment parameter for each gender, age group, and each of the 14 designs, and the results are shown in Table 8. Although gender or age group did not have any marked effect, design did have a marked effect.

Therefore, multiple comparisons were carried out for these 14 designs. Table 9 shows a part of the combinations of designs that resulted in significant mean value differences.

As for designs that received a good rating, Building $M$ showed significant differences in the mean value relative to nine designs. Similarly, Building I showed relative to eight designs, Buildings $\mathrm{G}$ and $\mathrm{J}$ relative to seven designs, respectively and Building $\mathrm{N}$ showed significant differences

Table 4. Average Score of Overall Judgment

\begin{tabular}{ccccccc}
\hline \multirow{2}{*}{ Ranking } & \multirow{2}{*}{ Design } & \multirow{6}{*}{ All } & \multicolumn{2}{c}{ Bverall Judgment Score } \\
\cline { 3 - 7 } & & & Males & Females & $20-30$ s & $40-50 \mathrm{~s}$ \\
\hline 1 & $\mathrm{M}$ & 5.65 & 5.69 & 5.62 & 5.80 & 5.52 \\
\hline 2 & $\mathrm{I}$ & 5.50 & 5.50 & 5.50 & 5.68 & 5.33 \\
\hline 3 & $\mathrm{~J}$ & 5.29 & 5.27 & 5.31 & 5.24 & 5.33 \\
\hline 4 & $\mathrm{~N}$ & 5.13 & 4.62 & 5.65 & 5.60 & 4.70 \\
\hline 5 & $\mathrm{G}$ & 5.12 & 5.15 & 5.08 & 5.24 & 5.00 \\
\hline 6 & $\mathrm{D}$ & 4.54 & 4.58 & 4.50 & 4.28 & 4.78 \\
\hline 7 & $\mathrm{~A}$ & 4.42 & 4.65 & 4.19 & 4.40 & 4.44 \\
\hline 8 & $\mathrm{~K}$ & 4.40 & 4.50 & 4.31 & 4.60 & 4.22 \\
\hline 9 & $\mathrm{C}$ & 4.25 & 4.00 & 4.50 & 4.48 & 4.04 \\
\hline 10 & $\mathrm{E}$ & 4.23 & 4.19 & 4.27 & 3.80 & 4.63 \\
\hline 11 & $\mathrm{~L}$ & 4.04 & 3.69 & 4.38 & 4.24 & 3.85 \\
\hline 12 & $\mathrm{~B}$ & 3.79 & 4.00 & 3.58 & 3.40 & 4.15 \\
\hline 13 & $\mathrm{H}$ & 3.58 & 4.04 & 3.12 & 3.64 & 3.52 \\
\hline 14 & $\mathrm{~F}$ & 3.25 & 3.08 & 3.42 & 2.92 & 3.56 \\
\hline
\end{tabular}

in the mean values relative to six designs. Regarding the designs that received a poor rating, Building $\mathrm{F}$ showed significant differences in the mean value relative to eleven designs. Similarly, Building $\mathrm{H}$ relative to six designs, and Buildings B, C, E and L showed significant differences in their mean values relative to five designs, respectively.

\subsection{Relationship among Gender and Age Groups, and Overall Judgment Scores}

For each design, the unpaired t test was conducted in terms of gender and age group. Table 10 shows designs that resulted in significant gender or age group differences in the mean value. Note that, for Buildings $\mathrm{H}$ and $\mathrm{N}$, significant gender differences were part of the difference in the mean values of overall scores. Also, for Buildings $\mathrm{E}$ and $\mathrm{N}$, significant age differences were part of the difference in the mean value for the overall

Table 5. Result of Factor Analysis

\begin{tabular}{crrr}
\hline & \multicolumn{1}{c}{ Factor 1 } & \multicolumn{1}{c}{ Factor 2 } & Factor 3 \\
\cline { 2 - 4 } & Visual Beauty & Disharmony & Potency \\
\hline Brightness & 0.803 & -0.77 & 0.080 \\
\hline Vividness & 0.765 & 0.005 & 0.233 \\
\hline Lightness & 0.750 & -0.120 & -0.127 \\
\hline Orderliness & 0.691 & -0.197 & -0.182 \\
\hline Beauty & 0.616 & -0.360 & 0.071 \\
\hline Freshness & 0.466 & -0.110 & 0.462 \\
\hline Harmony with surroundings & 0.013 & -0.908 & -0.109 \\
\hline Harmony of color between & 0.019 & -0.908 & -0.106 \\
\hline surroundings and greenery on wall & 0.158 & -0.716 & 0.068 \\
\hline Harmony with Building & 0.169 & -0.715 & 0.055 \\
\hline $\begin{array}{c}\text { Harmony of color between building } \\
\text { and greenery on wall }\end{array}$ & 0.229 & -0.484 & 0.215 \\
\hline Familiarity & -0.264 & -0.389 & 0.345 \\
\hline Naturalness & -0.216 & 0.002 & 0.723 \\
\hline Feeling of green & 0.042 & -0.121 & 0.638 \\
\hline Variety & 0.227 & 0.000 & 0.611 \\
\hline Uniqueness & 0.458 & 0.026 & 0.535 \\
\hline Gorgeousness & 0.414 & 0.020 & 0.466 \\
\hline Moisture & 24.40 & 50.68 & 58.38 \\
\hline Contribution ratio (\%) & & &
\end{tabular}

Table 6. Result 1 of Multiple Regression Analysis

\begin{tabular}{cccc}
\hline $\mathrm{R}$ & R square & Adjusted R square & Standard Error of estimate \\
\hline 0.869 & 0.755 & 0.754 & 0.741 \\
\hline
\end{tabular}

Table 7. Result 2 of Multiple Regression Analysis

\begin{tabular}{|c|c|c|c|c|c|}
\hline \multirow[t]{2}{*}{ Model } & \multicolumn{2}{|c|}{$\begin{array}{l}\text { Unstandardized } \\
\text { Coefficients }\end{array}$} & \multirow{2}{*}{$\begin{array}{c}\begin{array}{l}\text { Standardized } \\
\text { Coefficients }\end{array} \\
\text { Beta }\end{array}$} & \multirow{2}{*}{$\mathrm{t}$} & \multirow{2}{*}{$\begin{array}{c}\text { Significance } \\
\text { Probability }\end{array}$} \\
\hline & B & $\begin{array}{c}\text { Standard } \\
\text { Error } \\
\end{array}$ & & & \\
\hline (Constant) & 4.514 & 0.027 & & 164.453 & 0.000 \\
\hline Visual Beauty & 0.772 & 0.032 & 0.492 & 23.836 & 0.000 \\
\hline Disharmony & -0.597 & 0.033 & -0.384 & -18.102 & 0.000 \\
\hline Potency & 0.407 & 0.033 & 0.248 & 12.343 & 0.000 \\
\hline
\end{tabular}

Table 8. Results of Mixed analysis of variance

\begin{tabular}{ccc}
\hline Main Effect & F-Value \\
\hline $\begin{array}{c}\text { Differences as the interaction } \\
\text { by design and gender }\end{array}$ & $\mathrm{F}(13,611)=2.216$ & $\mathrm{p}<0.05$ \\
\hline $\begin{array}{c}\text { Differences as the interaction } \\
\text { by design and age group }\end{array}$ & $\mathrm{F}(13,611)=2.005$ & $\mathrm{p}<0.05$ \\
\hline Main effect of design & $\mathrm{F}(13,611)=19.19$ & $\mathrm{p}<0.01$ \\
\hline Main effect of gender & $\mathrm{F}(1,47)=0.00$ & $\mathrm{n} . \mathrm{s}$ \\
\hline Main effect of age group & $\mathrm{F}(1,47)=0.23$ & $\mathrm{n} . \mathrm{s}$ \\
\hline
\end{tabular}


scores.

\subsection{Interview Result}

Table 11 shows the main opinions of the interviews that were conducted as necessary in order to ask the respondents why they gave a certain rating to a particular building.

\section{Discussion}

This section discusses the results of this study by referring to the results of the interviews.

\subsection{Evaluating Factors}

Factor 1 was Visual Beauty. There were many comments in the interviews about orderliness of design and arrangement, leaf color tones, and quality of greenery management. Therefore, it is necessary to neatly arrange plants and also pay attention to the color of plants and their growth.

Factor 2 was Disharmony. Designs that were assessed in this study were designs created for cities and there was not much greenery around the buildings. In the interviews, too, there was a comment that "there was too much greenery on the building walls and it stood out from the

Table 9. Result of multiple comparisons

\begin{tabular}{|c|c|c|c|}
\hline $\begin{array}{c}\text { (I) } \\
\text { Design }\end{array}$ & $\begin{array}{c}(\mathrm{J}) \\
\text { Design }\end{array}$ & $\begin{array}{l}\text { Difference between } \\
\text { the means (I-J) }\end{array}$ & Standard Errors \\
\hline \multirow{9}{*}{ M } & $\mathrm{A}$ & $1.260 * *$ & 0.191 \\
\hline & $\mathrm{B}$ & $1.883 * *$ & 0.262 \\
\hline & $\mathrm{C}$ & $1.421 * *$ & 0.247 \\
\hline & $\mathrm{D}$ & $1.112 * *$ & 0.241 \\
\hline & $\mathrm{E}$ & $1.417 * *$ & 0.203 \\
\hline & $\mathrm{F}$ & $2.409 * *$ & 0.224 \\
\hline & $\mathrm{H}$ & $2.107 * *$ & 0.238 \\
\hline & $\mathrm{K}$ & $1.256 * *$ & 0.256 \\
\hline & $\mathrm{L}$ & $1.636 * *$ & 0.248 \\
\hline \multirow{8}{*}{ I } & $\mathrm{A}$ & $1.128 * *$ & 0.233 \\
\hline & $\mathrm{B}$ & $1.752 * *$ & 0.310 \\
\hline & $\mathrm{C}$ & $1.290 * *$ & 0.246 \\
\hline & $\mathrm{E}$ & $1.285 * *$ & 0.224 \\
\hline & $\mathrm{F}$ & $2.277 * *$ & 0.178 \\
\hline & $\mathrm{H}$ & $1.976 * *$ & 0.274 \\
\hline & $\mathrm{K}$ & $1.125 * *$ & 0.236 \\
\hline & $\mathrm{L}$ & $1.505 * *$ & 0.233 \\
\hline \multirow{7}{*}{ G } & $\mathrm{A}$ & $0.756^{*}$ & 0.187 \\
\hline & $\mathrm{B}$ & $1.380 * *$ & 0.282 \\
\hline & $\mathrm{C}$ & $0.918 * *$ & 0.170 \\
\hline & $E$ & $0.913 * *$ & 0.212 \\
\hline & $\mathrm{F}$ & $1.905 * *$ & 0.195 \\
\hline & $\mathrm{H}$ & $1.604 * *$ & 0.246 \\
\hline & $\mathrm{L}$ & $1.133 * *$ & 0.233 \\
\hline \multirow{7}{*}{$\mathrm{J}$} & $\mathrm{A}$ & $0.893 * *$ & 0.202 \\
\hline & $\mathrm{B}$ & $1.516^{* *}$ & 0.267 \\
\hline & $\mathrm{C}$ & $1.054^{*}$ & 0.253 \\
\hline & $E$ & $1.050 * *$ & 0.159 \\
\hline & $\mathrm{F}$ & $2.042 * *$ & 0.248 \\
\hline & $\mathrm{H}$ & $1.740 * *$ & 0.251 \\
\hline & $\mathrm{L}$ & $1.269 * *$ & 0.285 \\
\hline \multirow{6}{*}{$\mathrm{N}$} & $\mathrm{B}$ & $1.365 * *$ & 0.263 \\
\hline & $\mathrm{C}$ & $0.904 *$ & 0.236 \\
\hline & $E$ & $0.899 *$ & 0.237 \\
\hline & $\mathrm{F}$ & $1.891 * *$ & 0.199 \\
\hline & $\mathrm{H}$ & $1.590 * *$ & 0.259 \\
\hline & $\mathrm{L}$ & $1.119 * *$ & 0.191 \\
\hline
\end{tabular}

Based on estimated marginal means

*: Difference of mean is significant at $5 \%$ level

**: Difference of mean is significant at $1 \%$ level

a. Adjustment of multiple comparisons: Boneferroni surroundings in a strange way." When implementing vertical greenery in cities, it is necessary either to create a good balance of greenery between target buildings and their surroundings or to strongly promote greening of

Table 10. Differences of average value were significant by t-test

\begin{tabular}{cccc}
\hline & Design & \multicolumn{2}{c}{ T-Value } \\
\hline \multirow{2}{*}{ Gender } & $\mathrm{H}$ & $\mathrm{t}(50)=2.19$ & $\mathrm{p}<0.05$ \\
\cline { 2 - 4 } & $\mathrm{N}$ & $\mathrm{t}(40.307)=3.00$ & $\mathrm{p}<0.01$ \\
\hline \multirow{2}{*}{ Age Group } & $\mathrm{E}$ & $\mathrm{t}(50)=2.26$ & $\mathrm{p}<0.05$ \\
\cline { 2 - 4 } & $\mathrm{N}$ & $\mathrm{t}(50)=2.49$ & $\mathrm{p}<0.05$ \\
\hline
\end{tabular}

Table 11. Main opinions of evaluation reason on interview

\begin{tabular}{cl}
\hline Design & Main Opinions \\
\hline Common to & The building and its surroundings blend well with greenery. \\
\cline { 2 - 2 } High & The greenery is arranged nicely and neatly.
\end{tabular}

High The greenery is arranged nicely and neatly.

Evaluation The color of the plant (leaves) is light and beautiful.

The height of street trees and the location of greenery on the wall are

aligned with each other and they look good.

M I like the design in which plants and windows are arranged alternately.

The checkered pattern is beautiful.

Since vertical greenery is not a natural thing to start with, it looks better and blends in with the cityscape well if it maintains an artificial look.

I like the design in which greenery and windows are horizontally and

J alternately arranged.

I like landscape-oriented designs since they make greenery look larger.

The greenery is contained neatly within concrete frames. The greenery makes concrete walls look less cold.

The greenery does not blend well with the surrounding environment.

The wall surface area and the volume of greenery are not well

Low balanced (too Large or too Small).

Evaluation $\quad$ The color of leaves is dark or does not look clean.

I have a feeling that it is meaningless to implement greening in

F streets of buildings where there is no greenery around. The greenery is so localized that it looks artificial and experimental.

$5 \quad$ The building looks good because the greenery is not too localized.

Point The building with greenery makes me somehow nostalgic and I feel B an affinity to it.

B The volume of greenery is too large and it does not fit in the 2 surrounding environment

Point The greenery looks messy as it covers windows and signboards.

Males The design is good but the volume of greenery is not enough.

I like the harmony between the white walls and the green color of the

$\mathrm{N}$ Females plants.

I would prefer a small more greenery, but it still looks good as there is Large greenery around the building.

The greenery has a good volume but is designed poorly.

Males The building is covered with greenery and looks good from the distant or mid-range view

$\mathrm{H}$ The gap between greened walls and un-greened walls looks strange

Females to me

Many types of plants are mixed and it gives me an impression that plants are not well maintained.

\begin{tabular}{ll}
\hline \multirow{2}{*}{\begin{tabular}{ll} 
20-30s & The building itself looks good. \\
\cline { 2 - 3 } The building is cold looking but the greenery makes it look less cold.
\end{tabular}} \\
\hline The design is good but the volume of greenery is not enough.
\end{tabular}


the environment around the target buildings.

Factor 3 was Potency. Since high green coverage ratio was not directly translated into high overall scores, it is important to pay attention not only to mere plant volume but also to familiarity or texture of the plant. In the interviews, designs were rated high when plants and windows or plants and concrete surfaces were clearly separated and arranged alternately. There was also a comment that "vertical greenery was not natural from the beginning, so it would blend into the cityscape easily if its appearance stayed artificial." Some previous studies ${ }^{7,8)}$ claimed that artificial greenery would not fit in cities and would be something negative, but artificiality would not necessarily be negative in urban vertical greenery. It is important that greenery and buildings blend with each other beautifully and in an orderly way, and so, greenery should be systematically used as one of the exterior finishing materials and should be actively used in wall designs.

\subsection{Relationship between Design Characteristics and Overall Scores}

Among the designs that indicated significant differences in mean values as a result of mixed analysis of variance, which was conducted for the purpose of identifying the relationship between the designs and overall scores by referring to the results of the interviews. Table 12 shows the relationship between the design characteristics and overall scores that were either 5 or higher, or 4 or lower.

\section{(1) Greening Method}

The unit-type greening method was used in five designs that received high overall scores. This method allows designing of exterior walls of buildings with plants by creatively arranging greening units, and the effectiveness of this method was confirmed in this study. Note that the same method was used for Building $\mathrm{F}$, but the size of each unit was quite large $(1 \mathrm{~m} \mathrm{x} 2 \mathrm{~m})$ and the boundaries between units were not clear, because of which it was not possible to take advantage of the features of the unit-type greening method.

\section{(2) Shape of Greenery}

Four designs out of the five highest-rated designs had plants in horizontally wide spaces while two designs out of the three lowest-rated designs had plants in vertically tall spaces. In interviews, too, there were comments such as "horizontally wide green spaces look larger and nicer," and it seemed that horizontally wide greenery was favored more than vertically tall greenery.

\section{(3) Greenery Position}

Regarding the greenery position, three designs out of the five highest-rated designs had greenery at the bottom of the building, and one design had particularly dense greenery at the bottom of the building. For these four designs, there were comments in the interviews such as "plants were placed in good locations and looked beautiful as the height of the street trees and the plants on the wall were aligned with each other." Therefore, it appeared to be important to place greenery at the bottom of a building to make it closer to people. This finding agreed with the previous study results ${ }^{3,10)}$ that "greenery would blend in with the surrounding environment better when it was placed at the bottom of the building instead of at the top of it."

\section{(4)Green Coverage Ratio}

The ratio of the area of the building walls covered by plants was 13 to $36 \%$ for the five highest-ranked designs, and it became 25 to $58 \%$ when street trees around the buildings are also included. On the other hand, green coverage ratio including ratio covered with street trees for the three lowest-ranked designs was $2 \%, 71 \%$, and $80 \%$ respectively. Fig. 1 shows the relationship between the green coverage ratio and overall scores for all the 14 designs. From these, the following approximate formula was obtained:

$$
\mathrm{Y}=-0.0011 \mathrm{X}^{2}+0.0936 \mathrm{X}+3.07, \mathrm{R}^{2}=0.581
$$

According to this formula, green coverage ratio for designs with a score of 5 or higher was approximately 35 to $50 \%$. Considering that this result includes the surrounding greenery covering the building walls, the actual coverage by greening would be lower than the result reported by Koba et $\mathrm{al}^{2}$. In general, cities such as Tokyo and Osaka where the volume of plants around buildings was small, it appeared to be necessary to set the green coverage ratio at a little lower than that for subtropical cities to take the harmony with surrounding greenery volume. However, the green coverage ratio of the unit-type greening method that received high overall scores was 25 to $58 \%$. A further examination is necessary so that there is a possibility for this to influence the evaluation of green coverage ratio.

\section{(5) Wall Color}

Many of the buildings assessed in this study had either white or gray walls, and there was no clear relationship between wall colors and overall scores. However, there were many positive opinions in the interviews such as "cold-looking buildings could look warmer with plants" and this disagreed with the report that "it was likely that building walls and the

Table 12. Relation between Design and Overall Score

\begin{tabular}{ccccccc}
\hline Name & $\begin{array}{c}\text { Greening } \\
\text { Method }\end{array}$ & Shape & $\begin{array}{c}\text { Greenery } \\
\text { Position }\end{array}$ & $\begin{array}{c}\text { Green Coverage } \\
\text { Ratio Include } \\
\text { Street Trees (\%) }\end{array}$ & $\begin{array}{c}\text { Wall } \\
\text { Color }\end{array}$ & $\begin{array}{c}\text { Overall } \\
\text { Score }\end{array}$ \\
\hline M & Unit & HL & Lower & 33 & White & 5.65 \\
\hline I & Unit & VL & Other & 36 & Gray & 5.50 \\
\hline J & Unit & HL & Lower & 25 & White & 5.29 \\
\hline N & Unit & HL & Other & 58 & White & 5.13 \\
\hline G & Unit & HL & Lower & 28 & Gray & 5.12 \\
\hline B & CU & Other & Other & 71 & White & 3.79 \\
\hline H & CU & Other & Other & 80 & White & 3.58 \\
\hline F & Unit & VL & Other & 2 & White & 3.25 \\
\hline
\end{tabular}

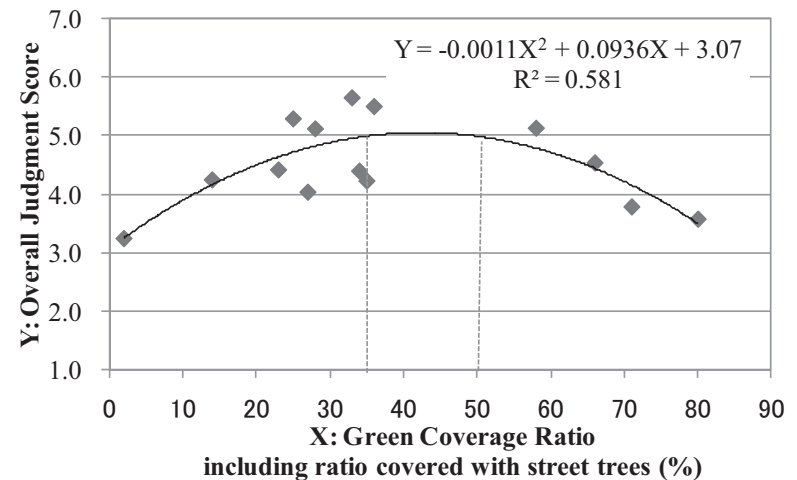

Fig. 1. Relation between Green Coverage Ratio and Overall Score 
green color of the plants were thought to clash with each other if the wall color was vivid or white." ${ }^{\text {(8) }}$ Because examples used in this study were buildings with systematic vertical greenery and their designs were created beforehand, this may have contributed to the prevention of any clash between the wall color and the green color of the plants.

\subsection{Relationship between Evaluating Factors and Overall Scores}

For the five designs that received the highest overall scores, Fig. 2 shows factor scores for the parameters included in the three factors introduced above. In Fig. 2, the factor score of Disharmony was reversed from the minus to the plus, and the factor name was changed with Harmony.

The factor scores of Visual Beauty received high for all these designs, while the scores for Harmony and Potency were different among these designs. Buildings $\mathrm{M}$ and $\mathrm{N}$ received a high score for Harmony, and Buildings I and $\mathrm{J}$ received a high score for Potency. It was assumed that these differences were caused from the difference of amount of greenery in the surrounding environment or the difference of vertical greenery design.

For the three designs that received the lowest overall scores, Fig. 3 shows factor scores obtained in the same manner as above. Although Buildings $\mathrm{B}$ and $\mathrm{H}$ with high green coverage received a relatively high score for Potency, scores for Visual beauty and Harmony were low.

Building $\mathrm{F}$ with extremely low green coverage of $2 \%$ received low scores for all evaluating factors. Therefore, its overall rating was quite low. In the interviews there were many negative comments related to the quantity of greenery being small, and some even commented that "it may be meaningless to green building in an area full of office buildings with no green around from the beginning." The same comment was made about Building $E$ which also was built in a street full of office buildings.

Therefore, greening must be carefully implemented if a street is lined with office buildings with no space in between and where there are no trees lining the street.

4.4 Relationship between Gender and Age Groups, and Overall Scores

Building $\mathrm{H}$ had a design with green coverage of $80 \%$ and was highly rated by male respondents while Building $\mathrm{N}$ had a design with green coverage of $13 \%$ and was highly rated by female respondents. For these 2 designs, Fig. 4 shows for each gender group the factor scores for the parameters included in the 3 evaluating factors.

For Building $\mathrm{H}$, male respondents gave higher scores than female respondents for all of the evaluating factors, but the difference of factor scores was small between these gender groups. It appeared that males might value Potency derive from high green coverage ratio more than females. But there was no significant score difference between the 2 gender groups for Building B with high green coverage of $71 \%$. This reason was that female's score of harmony was high because the amount of surrounding greenery of B Building was high, and the difference of overall scores between these gender groups became small. Therefore, it appeared that the difference of amount of surrounding greenery influenced the overall score.

Meanwhile, for Building N, female respondents gave higher scores for

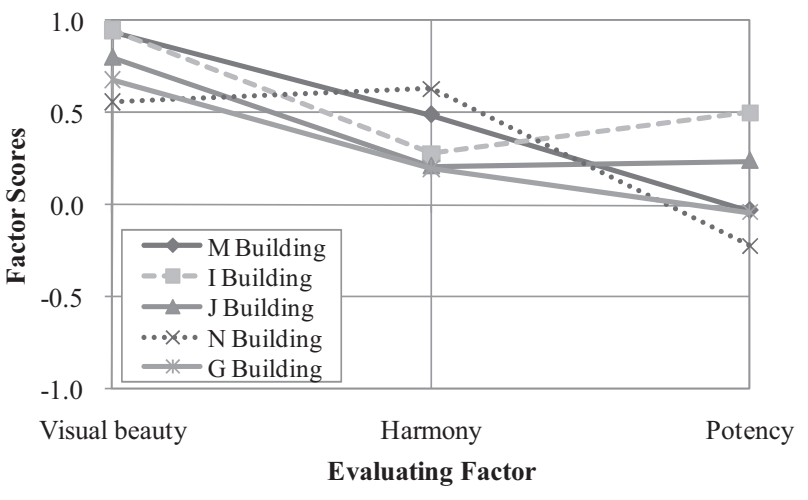

Fig. 2. Factor scores of buildings in high evaluation

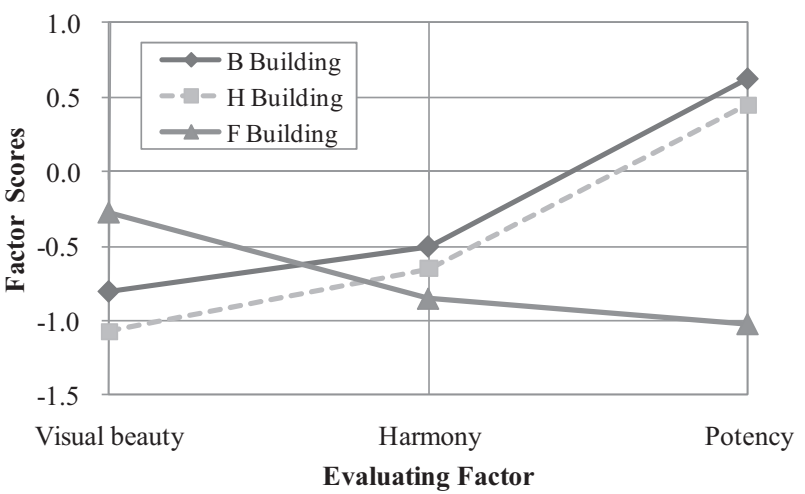

Fig. 3. Factor scores of buildings in low evaluation

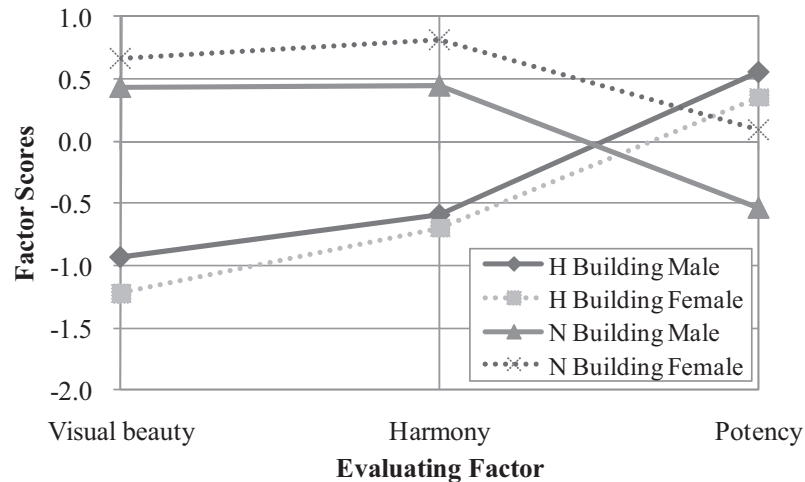

Fig. 4. Factor scores of buildings by gender

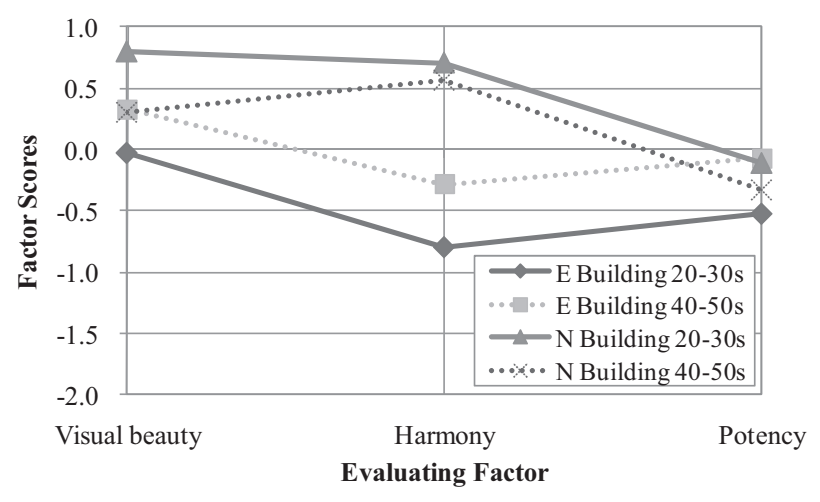

Fig. 5. Factor scores of buildings by generation 
all the evaluating factors than male respondents, and the score difference was particularly large for Potency. Males in general tended to consider the Potency important as well as H Building, and when the male respondents saw Building $\mathrm{N}$ with low green coverage ratio, they thought that this building had no strong impression and gave a low score since there were no windows on the walls and also the plants were spread all over the walls. This assumption was supported by the fact that there was no significant score difference between the two gender groups for Building $\mathrm{M}$ having windows and balconies, and plants were concentrated at the bottom of the building, giving a strong impression.

Next, for Buildings E and N, Fig. 5 shows for each age group the mean values of factor scores for the parameters included in the 3 evaluating factors.

For Building E, respondents in their 40's and 50's gave higher scores than respondents in their 20 's and 30 's regarding all of the evaluating factors. In the interview, respondents in their 20's and 30's gave negative comments in terms of Harmony and Potency saying that "the design was boring and plain, and it stood out from other buildings in an unfavorable way." Respondents in their 40's and 50's, on the other hand, gave positive comments in terms of Visual Beauty and Potency saying that "although the design did not blend well with the surrounding environment, it was nice and simple, and stood out in a good way." Building E had vertically tall greenery just like the shape of the building itself and its green coverage ratio was relatively high at $35 \%$; therefore, it seemed that a high score was given by respondents in their 40 's and 50 's who considered Potency.

However, for Building N, respondents in their 20's and 30's gave higher scores than respondents in their 40's and 50's regarding all the evaluating factors, and the score difference was relatively large for Visual Beauty between these 2 age groups. In the interview, respondents in their 20's and 30 's gave positive comments in terms of Visual Beauty saying that "the building itself looks good." Respondents in their 40's and 50's, on the other hand, gave negative comments in terms of Potency saying that "the design is good but the volume of greenery is not enough." As in the case of gender difference, Building $\mathrm{N}$ with a weak impression derive from low green coverage ratio was considered to have received a low score by respondents in their 40's and 50's.

\section{Conclusion}

The study suggested the following regarding vertical greenery design in cities:

There were 3 evaluating factors. Factor 1 was Visual Beauty, Factor 2 was Disharmony, and Factor 3 was Potency. In factor 1, plants should be neatly arranged with special attention paid to their color and growth. In factor 2, a good balance of greenery between subject buildings and their surroundings should be created, and greening of the environment around subject buildings should be actively promoted. In factor 3, plants should be actively utilized as a building design element even though it may seem artificial

The preferable greening method was the unit-type greening method.
Horizontally wide greening at the bottom of building walls with 35 to $50 \%$ green coverage ratio including street trees was likely to receive a high overall judgment score. Greening must be carefully implemented if a street is lined with office buildings with no space in between and where there are no trees lining the street.

Female respondents tended to consider Visual Beauty as important, while male respondents tended to consider Potency as important. Respondents in their 40's and 50's tended to consider Potency as important more than respondents in their 20's and 30's.

\section{Acknowledgement}

We wish to thank Dr. Eiichi Sawada, Mr. Mamoru Nasu, Mr. Atsushi Kannari, Dr. Shigehiro Yokota, Mr. Mark Sueyoshi and Ms. Nobue Shibuya of Shimizu Corporation for their support and encouragement.

\section{References}

1) Ministry of Land, Infrastructure and Transport : A research about construction area of rooftop garden and vertical greenery in Japan, Press release, 2008

2) Koba $K$ and Ikeda $T$ : A study on the Estimation and Type of Wall Greening in City on the Subtropical Zones, Proceedings of Annual Scientific Meeting of Architectural Institute of Japan, pp.217-218, 1985

3) Ikeda $T$, Koba $\mathrm{K}$ and Taira $\mathrm{H}$ : Forms of Green on Elevation and its Evaluation in Naha Residential Area, Proceedings of faculty of engineering of University of the Ryukyus No.26, pp.47-66, 1983

4) Sawada M, Senda M and Kawakami M : A Study on Visual Effects of Greening Wall Planning on Buildings, Proceedings of Annual Scientific Meeting of Architectural Institute of Japan, pp.857-858, 2000

5) Sawada M, Senda M, Kawakami M : Evaluation of the Environment by Green Space and Architecture, Proceedings of Annual Scientific Meeting of Architectural Institute of Japan, pp.329-330, 2003

6) Okita T, Sato S, Kobayashi Y and Himeno Y : Basic Research for Development of Road Landscape Evaluation System and Evaluation Method using Virtual Reality, Proceedings of Annual Scientific Meeting of Architectural Institute of Japan, pp. 1049-1050, 2004

7) Okita T, Sato S, Kobayashi Y and Himeno Y : The Visual Effect of The Building Planting Trees in The City, Proceedings of Annual Scientific Meeting of Architectural Institute of Japan, pp. 251-252, 2005

8) Sakuma M and Muto H : A Study of Recent Research on Planting on Building Walls and the Greening Landscape Evaluation Framework, Collected Papers for the 17th Technological Research Meetings of The Urban Infrastructure \& Technology Promotion Council, Category of Town Development, No.2, 2005

9) Nakamura K, Nasu M, Yakushiji K, Kita M, Koutani S and Kashiwagi : A Vertical greenery technology and its effect used special soil, Collected papers of 19th technological research meetings of The Urban Infrastructure \& Technology Promotion Council, pp.156-161, 2007

10) Nakamura K, Nasu M and Kita M : A study on designs of green wall of unit type, Proceedings D1 of Annual Scientific Meeting of Architectural Institute of Japan, pp.1031-1032, 2008

11) Köhler $M$ : Green facades -a view back and some visions, Urban Ecosyst No.11, pp.423-436, 2008

12) Wong NH, Tan AYK, Chen Y, et al. : Thermal evaluation of vertical greenery systems for building walls, Building and Environment 45, pp.663-672, 2010

Kita M, Oku T, Funahashi K and Kamino K: Relationship between Estimation and Color Combination of Facades with Operation of Cityscape Elements, Japan Architect. Plann. Environ. Eng., Architectural Institute of Japan, No.516, pp. 177-184, 1999. 


\section{和文要約}

ヒートアイランド現象緩和や景観向上などを目的に、都市部の建 物では緑化が積極的に行われており、特に近年は、壁面緑化を採用 する建物が増加している。しかし壁面緑化は建物の外観へ直接影響 を与えるものであり、都市の景観改善や都市生活者の快適性向上に 寄与寸るためには、壁面緑化の印象について検討寸る必要がある。 そこで本研究では、東京、横浜、大阪などの都市部において、意 図的に壁面緑化された建物の中から、先駆的な事例、財団法人都市 緑化技術開発機構などが主催した壁面緑化に関するコンクールにお いて表彰された好事例 14 件を抽出した。そして S D 法によるデザイ ン評価を実施し、評価因子やデザイン上の留意点、性別や年齢によ る差異について確認した。その結果、以下のようなことが明らかと
なった。

1 、壁面緑化の評価因子は 3 つで、第 1 因子が「美観性」、第 2 因子 が「不調和性」、第 3 因子が「力量性」であった。

2. 緑化方法ではユニット型と呼ばれる手法、緑化形状は横長形状、 緑化位置は建物壁面の下部、壁面緑被率は壁面を覆う街路樹等 の周囲の緑も含め 35 50\%のものの評価が高くなった。なお緑 被率については評価の高いユニット型手法の事例の緑被率が影 響を及ぼした可能性があり、更なる検討が必要である。

3. 性別や年齢による差異が確認された建物の比較において、男性 は「力量性」を重視し、緑被率の高い建物を女性よりも高く評 価する傾向が、また 20〜30 代は「美観性」を、40～50 代は「力 量性」を重視する傾向が見られた。

（2009年11月10日原稿受理，2010年 4 月26日採用決定） 